\title{
Splitting of Malus microcuttings enhances rooting
}

\author{
J Puente, JA Marín* \\ CSIC, Pomologia, Estación Experimental'Aula Dei', Apdo 202, 50080 Zaragoza, Spain \\ (COST Meeting, 21-23 May 1992, Dijon, France)
}

\begin{abstract}
Summary - Basal longitudinal splitting $(2 \mathrm{~mm}$ ) of microcuttings from the apple rootstock M9 (Jork 9 ) markedly enhanced their rooting ability in vitro. Most of the rooted plants survived after planting in soil and showed normal growth. Shoots were split longitudinally producing 2 similar halves to compare their responses. There was a significant correlation between the rooting capabilities of each half of 1 shoot. This is discussed in terms of differences in the physiological state among shoots.
\end{abstract}

\section{Malus x domestica / splitting / rooting / in vitro / micropropagation}

Résumé - La fente des microboutures de Malus pour l'enracinement in vitro. La capacité d'enracinement in vitro de microboutures du porte-greffe de pommier M9 (Jork 9) a été notablement augmentée en fendant la partie basale $(2 \mathrm{~mm})$. Les plantes enracinées ont survécu et se sont développées normalement pendant l'acclimatation. Pour étudier la capacité d'enracinement des différentes parties de la même microbouture, les microboutures ont été fendues sur toute leur longueur en 2 moitiés semblables dont les capacités d'enracinement se sont montrées sensiblement corrélées. Ces résultats pourraient être expliqués par le fait que l'état physiologique varie fortement entre les microboutures, mais qu'il est le même dans les 2 moitiés de chaque microbouture.

Malus $x$ domestica / fente / enracinement / in vitro / micropropagation

\section{INTRODUCTION}

Jork 9 (J9) is an interesting and difficult-to-root clone of the M9 apple (Malus $x$ domestica Borkh) rootstock. Its rooting ability in vitro varies widely among batches (from 15-85\%), the mean value being $55 \%$ (unpublished results). Consistent high rooting percentages are desirable for mass propagation and for the study of adventitious root induction.

Wounding has long been known to enhance rooting of conventional cuttings from woody species (Hartman and Kester, 1968). Snir and Erez (1980) adapted this technique for microcuttings of "Malling Merton" apple rootstocks, and Sriskandarajah and Mullins (1981) for cV Granny Smith. The aim of the present work was to examine whether rhizogenesis in vitro of $\mathrm{J9}$ was improved by splitting. We also studied the possible correlation between the rooting abilities of halves obtained from 1 shoot.

\section{MATERIALS AND METHODS}

J9 shoot cultures which had been initiated in the Central Research Laboratory for Tissue Culture of Horticultural Crops (Lisse, NL) and grown in vitro for $>5 \mathrm{yr}$ were used. The proliferation medium was a modified MS medium (Murashige and Skoog, 1962) with $30 \mathrm{~g} / \mathrm{D}$-sorbitol instead of sucrose and $1 \mathrm{mg} / \mathrm{l}$ benzylaminopurine (BA) and $0.1 \mathrm{mg} / \mathrm{l}$ indole-3butyric acid (IBA). The rooting medium was based on that of Quoirin and Lepoivre (1977) with macroelements at half-strength, $0.2 \mathrm{mg} / \mathrm{IBA}, 1 \mathrm{mg} / \mathrm{l}$ riboflavin and $100 \mathrm{mg} / \mathrm{l}$ proline. Cultures were subcultured at 6-wk intervals, and placed in a growth chamber at $24 \pm 2{ }^{\circ} \mathrm{C}$. Shoots $>2 \mathrm{~cm}$ were used for rooting. All manipulations were carried out in a laminar air-flow cabinet.

In the first experiment, the basal $2 \mathrm{~mm}$ of shoots $(n=84)$ were split longitudinally. These and unsplit shoots $(n=79)$ were placed in baby food jars (Sigma $\mathrm{V}-8630$ ) with $20 \mathrm{ml}$ of medium (5 shoots/jar) or in polypropylene vessels (Sigma P-4928) containing $80 \mathrm{ml}$ of medium (12 shoots/jar). They were first kept in darkness for $7 \mathrm{~d}$ and then exposed to a 16-h pho-

\footnotetext{
* Correspondence and reprints
} 
toperiod within the growth chamber. One month later rooting percentages and numbers of roots per rooted shoot were recorded. The rooted plants were transferred to pots with peat: perlite $(1: 1, v / v)$ and placed in polystyrene mini-greenhouses in the growth chamber. The lids were removed daily for increasing periods of time.

In the second experiment, 42 shoots were longitudinally split totally into 2 similar halves. Two pairs of halves were placed into each baby food jar containing $20 \mathrm{ml}$ rooting medium. Unsplit shoots $(n=44)$ were treated as in the experiment above and the culture conditions remained the same. Presence or absence of roots $>1$ and $2 \mathrm{~mm}$ was recorded after 1 month and the correlation between both halves from each shoot was studied using the $\chi^{2}$ test, comparing the observed values with the probability of both shoot halves to produce the same rooting response $\left[P^{R}+\right.$ $\left.(1-P)^{2}\right]$ or a different one $[2 P(1-P)]$, provided that rooting is at random and $P$ is the probability of a shoot half to root.

\section{RESULTS}

\section{Basal splitting}

The first experiment showed that $71.4 \%$ of the basally split plants rooted, as opposed to only $40.5 \%$ of the unsplit shoots. This increase was found to be very significant $(P<0.01)$. A significantly $(P<0.01)$ higher number of roots per rooted shoot was observed in the split microcuttings than in the unsplit ones (table I). One month after the transfer to pots, $76.8 \%$ of the rooted split plants were actively growing with the lids removed.

\section{Complete splitting}

In the second experiment, we found that $63.1 \%$ of the shoot halves had produced roots $\geq 2 \mathrm{~mm}$. Up to $94.1 \%$ of the shoot halves had roots $\geq 1$ $\mathrm{mm}$. Under this treatment, many root primordia failed to elongate. Only $15.9 \%$ of the unsplit shoots rooted. Both halves from 1 shoot showed a similar rooting response (ie both or none of them had roots $>2 \mathrm{~mm}$ ) in the $78.6 \%$ of the shoots (fig 1). This is significantly more $(P<$ 0.01 ) than the expected value if the shoot halves rooted at random. There was no correlation between the number of roots of halves of the same shoot.

\section{DISCUSSION AND CONCLUSION}

Basal injuries of $\mathrm{J} 9$ microcuttings had a favourable effect on both rooting percentage and number of roots per rooted shoot. An increase in the number of roots was also recorded by Sriskandarajah and Mullins (1981), but these authors did not find a significant difference in the rooting percentage. The improvement in rooting might be due to: 1) increased penetration of the added IBA into the tissues; 2) a "wound hormone" (cf George and Sherrington, 1984); or 3) the disruption of the phloem sclerenchymatous fibre sheath, which has been suggested to act as a physical barrier against the cambium proliferation in shy-rooting conventional cuttings (Beakbane, 1961; Pontikis et al, 1979). However, the latter is not the only cause of failure to root since, in many plants, root initials do not form at all (Beakbane, 1961). New approaches using histochemi-

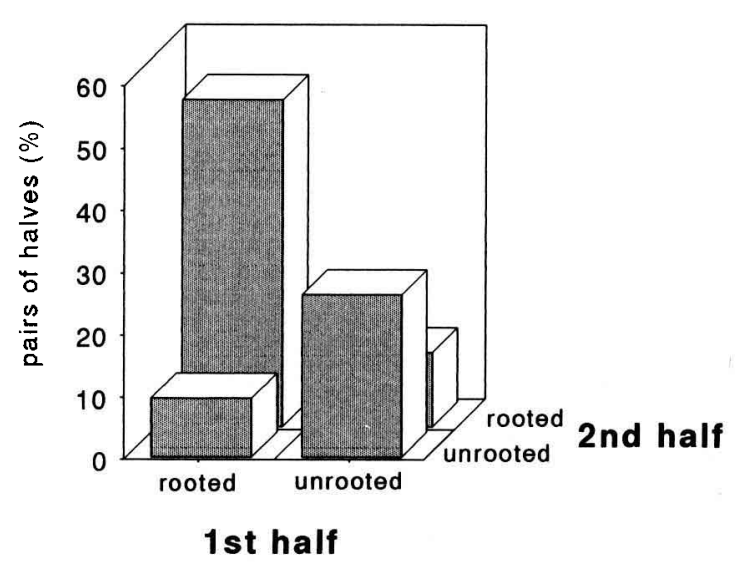

Fig 1. Percentages of pairs of halves of Jork 9 microcuttings showing different combinations of responses. Only roots $\geq 2$ $\mathrm{mm}$ were considered.

Table I. Effect of basal splitting on rooting of Jork9 microcuttings.

\begin{tabular}{lccc}
\hline & $n$ & $\%$ Rooting & $\begin{array}{c}\text { No of roots/ } \\
\text { rooted shoot } \\
( \pm S E)\end{array}$ \\
\hline Split shoots & 84 & $71.4^{\mathrm{a}}$ & $6.3( \pm 0.4)^{\mathrm{a}}$ \\
Controls & 79 & $40.5^{\mathrm{b}}$ & $3.4( \pm 0.2)^{\mathrm{b}}$ \\
\hline
\end{tabular}

Different letters in the same column indicate significant differences $(P<0.01)$. 
cal and biochemical techniques seem to be needed to understand the effect of wounding in root formation.

There is a strong variation in the rooting ability of $\mathrm{J} 9$ between batches and among shoots within each batch. On the other hand, we have shown that there is a high correlation in the rooting response of halves obtained from one shoot. This suggests differences in the physiological state among shoots, which do not exist between both halves. Such differences must be concretely determined and may include: the endogenous growth regulator levels within the microcutting, its efficiency of perception of the stimulus and its competence to regenerate roots (Van der Krieken et al, 1992).

\section{ACKNOWLEDGMENTS}

This study was carried out under the COST 87 project and was partly financed by a grant (PCA 8/89) and a scholarship (BCA-16/91) to JP both from CONAIDiputación General de Aragón, Spain.

\section{REFERENCES}

Beakbane AB (1961) Structure of the plant stem in relation to adventitious rooting. Nature 192, 954-955

George EF, Sherrington PD (1984) Plant Propagation by Tissue Culture. Exegetics Ltd, Basingtoke, UK

Hartman Ht, Kester DE (1968) Plant Propagation: Principles and Practices. Prentice-Hall, Englewood Cliffs, New Jersey, USA 2nd edn

Murashige T, Skoog $F$ (1962) A revised medium for rapid growth and bioassays with tobacco tissue culture. Physiol Plant 15, 473-497

Pontikis CA, Mackenzie KAD, Howard BH (1979) Establishment of initially unrooted stool shoots of M27 apple rootstock. J Hortic Sci 54, 79-85

Quoirin M, Lepoivre P (1977) Improved media for in vitro culture of Prunus sp. Acta Hortic 78, 437-442

Snir I, Erez A (1980) In vitro propagation of Malling Merton apple rootstocks. HortSci 15, 597-598

Sriskandarajah S, Mullins MG (1981) Micropropagation of Granny Smith apple: factors affecting root formation in vitro. J Hortic Sci 56, 71-76

Van der Krieken WM, Breteler H, Visser MHM, Jordi $W$ (1992) Effect of light and riboflavin on indolebutyric acid-induced root formation on apple in vitro. Physiol Plant 85, 589-594 